\title{
Maitotilojen menestyminen ja kehittämisstrategiat
}

Heikki Mäkinen, Helsingin yliopisto, Taloustieteen laitos

heikki.makinen@helsinki.fi

\section{Tiivistelmä}

Tutkimuksen tavoitteena oli selvittää, millaisia yritystoiminnan kehittämisstrategioita maidontuottajilla on ja mistä komponenteista ne muodostuvat sekä tarkastella, millaisia ovat taloudelliset toimintaedellytykset eri kehittämisstrategioita suunnittelevilla tiloilla. Aineistona käytettiin MTT:n kannattavuuskirjanpitoon kuuluvia maitotilojen tilinpäätöksiä vuosilta 2000-2007 sekä kirjanpitokyselyä vuodelta 2007. Aineistossa oli 125 tilaa ja sitä analysoitiin pääkomponentti- ryhmittely- ja varianssianalyyseillä.

Tulosten perusteella maidontuottajat voidaan ryhmitellä erilaisten kehittämisaikomusten perusteella säilyttäjien, toiminnan uudelleen suuntaajien, laajentamishakuisten ja voimakkaasti laajentamishakuisten ryhmiin. Suurella osalla maidontuottajista näytti olevan edelleen halua laajentaa tuotantoaan. Laajentamishakuisuus oli yhteydessä jo aiemmin toteutuneeseen tilakoon kasvuun. Laajentamiseen liittyi myös halu kehittää yhteistyötä toisten tilojen ja muiden yhteistyökumppanien kanssa. Laajentamishakuiset yrittäjät ovat myös muita valmiimpia lisäämään vieraan pääoman käyttöä ja ottamaan riskejä. Kasvuhakuisten yrittäjien tilojen kannattavuus ja sen kehitys vuosina 2000 - 2007 ei ollut olennaisesti muista tiloista poikkeava. Tuotannon uudelleen suuntaaminen näytti olevan yhteydessä tilan sukupolvenvaihdostilanteeseen.

\section{Asiasanat}

maidontuotanto, kehittäminen, kannattavuus, strategia, kasvu, menestyminen 


\section{Johdanto}

Maatalousyrityksen liikkeenjohdossa yrittäjän keskeinen tehtävä on yrityksen toiminnan kehittäminen ja sopeuttaminen siten, että se vastaa parhaalla mahdollisella tavalla toisaalta yrittäjän yritystoiminnalle asettamia pitkän aikavälin tavoitteita ja toisaalta toimintaympäristössä tapahtuvia muutoksia. Toimintaympäristön muutoksista keskeisimpiä ovat hintasuhteiden ja yhteiskunnan harjoittaman politiikan muutokset, tuotantoteknologian kehittyminen sekä kilpailutilanteen muuttuminen muiden yrittäjien sekä elintarvikesektorin muiden toimijoiden päätösten ja toiminnan seurauksena. Maatilan kehittämisen lähtökohtana voidaan kuitenkin pitää yrittäjän tavoitteita ja sitä, kuinka hyvin ne on tähän saakka saavutettu - menestymistä (Mäkinen ja Ylätalo 2008). Hyvin menestyneen maatilan edelleen kehittämiselle on suotuisat lähtökohdat, ja tällöin yrittäjällä saattaa olla useitakin erilaisia vaihtoehtoja valittavanaan. Heikko menestyminen puolestaan saattaa olla signaali siitä, että yrityksen toimintoja on tarpeen tarkastella uudelleen, mikä taas saattaa merkitä radikaalejakin muutoksia aiempaan toimintaan. Heikko taloudellinen menestyminen merkitsee myös sitä, että lähtökohdat yritystoiminnan edelleen kehittämiselle ovat heikot.

Tämän tutkimuksen tavoitteena oli selvittää, millaisia yritystoiminnan kehittämisstrategioita maidontuottajilla on ja mistä komponenteista ne muodostuvat sekä tarkastella, millaisia ovat taloudelliset toimintaedellytykset eri kehittämisstrategioita suunnittelevilla tiloilla. Lisäksi tavoitteena oli tarkastella, miten maatilan elinkaaren vaihe vaikuttaa yrittäjän kehittämissuunnitelmiin.

\section{Aineisto ja menetelmät}

Tutkimuksessa analysoitiin niitä MTT:n kannattavuuskirjanpitoon kuuluvia tiloja, joiden tuotoista pääosa tulee maidontuotannosta. Kehittämisstrategioita ja tilan elinkaaren vaihetta koskeva aineisto koottiin kevään 2007 kirjanpitokyselyllä, johon vastasi 125 maidontuottajaa. Vastauksista osa oli puutteellisia, joten kyselyaineiston osalta analyyseissä pystyttiin hyödyntämään 115 tuottajan vastauksia. Kyselyaineistoon yhdistettiin tilojen tilinpäätöstiedot vuosilta 2000 - 2007. Tilamäärä väheni ajassa taaksepäin mentäessä siten, että tilinpäätöstietojen ja kyselyaineiston yhdistely oli mahdollista 70 tilalle vuonna 2000 ja 110 tilalle vuonna 2007.

Kehittämisaikomuksia koskevia kyselyn osioita analysoitiin pääkomponenttianalyysin ja ryhmittelyanalyysin avulla. Pääkomponenttianalyysillä tiivistettiin kyselyaineisto erilaisia kehittämissuuntia kuvaaviksi muuttujiksi, ja ryhmittelyanalyysillä tuottajat jaettiin erilaisia kehittämisstrategioita suunnitteleviin ryhmiin. Eri kehittämisstrategioita suunnittelevien maidontuottajien tilojen taloudellisessa tilanteessa ilmeneviä eroja tutkittiin varianssianalyysillä, minkä lisäksi kehittämisaikomusten ja tilan elinkaaren vaiheen välistä yhteyttä tarkasteltiin ristiintaulukoinnilla.

\section{Tulokset}

Maidontuottajien tulevaisuuden kehittämisaikomuksia koskevia kysymyksiä oli kirjanpitokyselyssä alun perin 27. Maidontuottajia pyydettiin arvioimaan kuinka hyvin erilaiset tilan kehittämiseen liittyvät toimintatavat sopivat heidän tilanpitoonsa ja tavoitteisiinsa. Vastausvaihtoehdot noudattivat viisiportaista likert-asteikkoa. Vastausten sisältämää informaatiota tiivistettiin pääkomponenttianalyysillä. Pääkomponenttien muodostamisessa edettiin eksploratiivisesti. Alustavien analyysien perusteella alkuperäisistä kysymyksistä poistettiin osa, jotta havaintojen ja kysymysten määrän välinen suhde saatiin luotettavan analyysin kannalta riittävän suureksi ja jotta pääkomponenttien tulkinta olisi mahdollisimman selkeä (vrt. esim. Hair ym. 2005, s. 113). Karsintaa tehtiin toisaalta kysymysten sisällön perusteella turhan toiston välttämiseksi sekä toisaalta alustavissa analyyseissä havaittujen alhaisten kommunaliteettien ja voimakkaiden ristilatausten perusteella siten, että lopulliset kehittämisaikomuksia kuvaavat summamuuttujat muodostettiin 19 kysymyksestä (taulukko 1).

Pääkomponenttianalyysissä päädyttiin neljän pääkomponentin ratkaisuun (taulukko 1), jolla kyettiin selittämään noin 58\% kyselyn muuttujien varianssista. Varimax-rotaation jälkeen maidontuottajien kehittämisaikomuksia kuvaavat neljä pääkomponenttia voitiin nimetä seuraavasti: "toiminnan uudelleen suuntaaminen", "nykytuotannon säilyttäminen", "tuotannon laajentaminen" ja "yhteistyön lisääminen”. 
Taulukko 1. Kehittämisaikomuksia kuvaavien muuttujien Varimax-rotatoitu pääkomponenttiratkaisu: muuttujien lataukset ja pääkomponenttien ominaisarvot (itseisarvoltaan alle $0,35: \mathrm{n}$ suuruiset lataukset on poistettu).

\begin{tabular}{|c|c|c|c|c|}
\hline \multirow[b]{2}{*}{$\begin{array}{l}\text { Maatilan kehittämiseen liittyvä } \\
\text { toimintatapa }\end{array}$} & \multicolumn{4}{|c|}{ Pääkomponetti } \\
\hline & $\begin{array}{l}\text { Toiminnan } \\
\text { uudelleen } \\
\text { suuntaaminen }\end{array}$ & $\begin{array}{l}\text { Nykytuotannon } \\
\text { säilyttäminen }\end{array}$ & \begin{tabular}{|l} 
Tuotannon \\
laajentaminen
\end{tabular} & $\begin{array}{l}\text { Yhteistyön } \\
\text { lisääminen }\end{array}$ \\
\hline Sivuelinkeinon kehittäminen & 0,762 & & & \\
\hline Päätuotantosuunnan vaihtaminen & 0,750 & & & \\
\hline Uusien tuotannonalojen käynnistäminen & 0,720 & & & \\
\hline Tuotteiden jatkojalostus tilalla & 0,690 & & & \\
\hline Tuotannon monipuolisuus & 0,673 & & & \\
\hline Työskentely tilan ulkopuolella & 0,588 & & & \\
\hline Tilan maksuvalmiuden turvaaminen & & 0,718 & & \\
\hline $\begin{array}{l}\text { Tuotantoeläinten hyvinvoinnista huolehti- } \\
\text { minen }\end{array}$ & & 0,710 & & \\
\hline Tuotteiden korkea laatu & & 0,700 & & \\
\hline $\begin{array}{l}\text { Oman ammattitaidon kehittäminen (koulu- } \\
\text { tus, kurssit, omatoiminen) }\end{array}$ & & 0,661 & 0,350 & \\
\hline Tilan perinteiden jatkaminen & & 0,559 & & \\
\hline $\begin{array}{l}\text { Keskittyminen tilan vahvimpaan tuotan- } \\
\text { tosuuntaan }\end{array}$ & & 0,556 & & \\
\hline $\begin{array}{l}\text { Taloudellisen riskin pitäminen mahdolli- } \\
\text { simman pienenä }\end{array}$ & & & $-0,853$ & \\
\hline $\begin{array}{l}\text { Velkamäärän pitäminen mahdollisimman } \\
\text { pienenä }\end{array}$ & & & $-0,793$ & \\
\hline Yrityskoon kasvattaminen & & & 0,684 & \\
\hline Investoiminen uusimpaan teknologiaan & & & 0,601 & \\
\hline Ostopalveluiden käyttö (esim\# urakointi) & & & & 0,788 \\
\hline Sopimustuotanto & & & & 0,724 \\
\hline $\begin{array}{l}\text { Yhteistyö muiden tilojen kanssa (esim. } \\
\text { yhteiskoneet, työnvaihto) }\end{array}$ & & 0,374 & & 0,643 \\
\hline Pääkomponenttien ominaisarvot & 4,67 & 3,12 & 2,13 & 1,16 \\
\hline
\end{tabular}

Kullekin maidontuottajalle muodostettiin heidän kehittämisaikomuksiaan kuvaavat summamuuttujat pääkomponenteille ensisijaisesti latautuville kysymyksille annettujen vastausten keskiarvona. Pääkomponenttianalyysissä negatiivisen latauksen saaneiden muuttujien arvot kuitenkin käännettiin summamuuttujia muodostettaessa päinvastaisiksi vähentämällä luvusta kuusi alkuperäinen vastauksen arvo (1 - 5). Summamuuttujia käytettiin pääkomponenttipisteiden sijasta siksi, että ne kuvaavat vain kyseisen pääkomponentin tärkeimpiä piirteitä ja ovat komponenttipisteitä helpommin tulkittavia (esim. Hair ym. 2005, 140).

Maidontuottajat voitiin summamuuttujien perusteella ryhmitellä neljään strategiaryhmään: säilyttäjät, uudelleen suuntaajat, laajentamishakuiset ja voimakkaasti laajentamishakuiset. Summamuuttujien arvojen jakaumat näissä ryhmissä käyvät ilmi kuviosta 1. Kaikissa ryhmissä summamuuttuja "nykytuotannon tehostaminen" sai keskimäärin varsin korkeita arvoja, joten ryhmien väliset erot syntyivät pääasiassa muiden tekijöiden perusteella. Ryhmiä voidaan kuvata seuraavasti:

1. Säilyttäjien ryhmään kuului 11 maidontuottajaa. Tässä ryhmässä summamuuttujat "uudelleen suuntaaminen", "laajentaminen" ja "yhteistyö" saivat melko alhaisia arvoja. 
2. Uudelleen suuntaajiin kuului 29 maidontuottajaa. Heillä "uudelleen suuntaaminen" summamuuttujan arvot olivat tyypillisesti korkeampia kuin muissa ryhmissä, minkä lisäksi "yhteistyö"-muuttujan arvot olivat tyypillisesti melko korkeita.

3. Laajentamishakuisten maidontuottajien ryhmä ( 28 tuottajaa) erosi säilyttäjistä lähinnä siten, että tässä ryhmässä summamuuttujat "laajentaminen" ja "yhteistyö" saivat tyypillisesti korkeampia arvoja kuin säilyttäjien ryhmässä.

4. Voimakkaasti laajentamishakuisten maidontuottajien ryhmässä (42 tuottajaa) erottelevimmat piirteet olivat muuttujien "laajentaminen" ja "yhteistyö" muita ryhmiä selvästi korkeammat arvot.

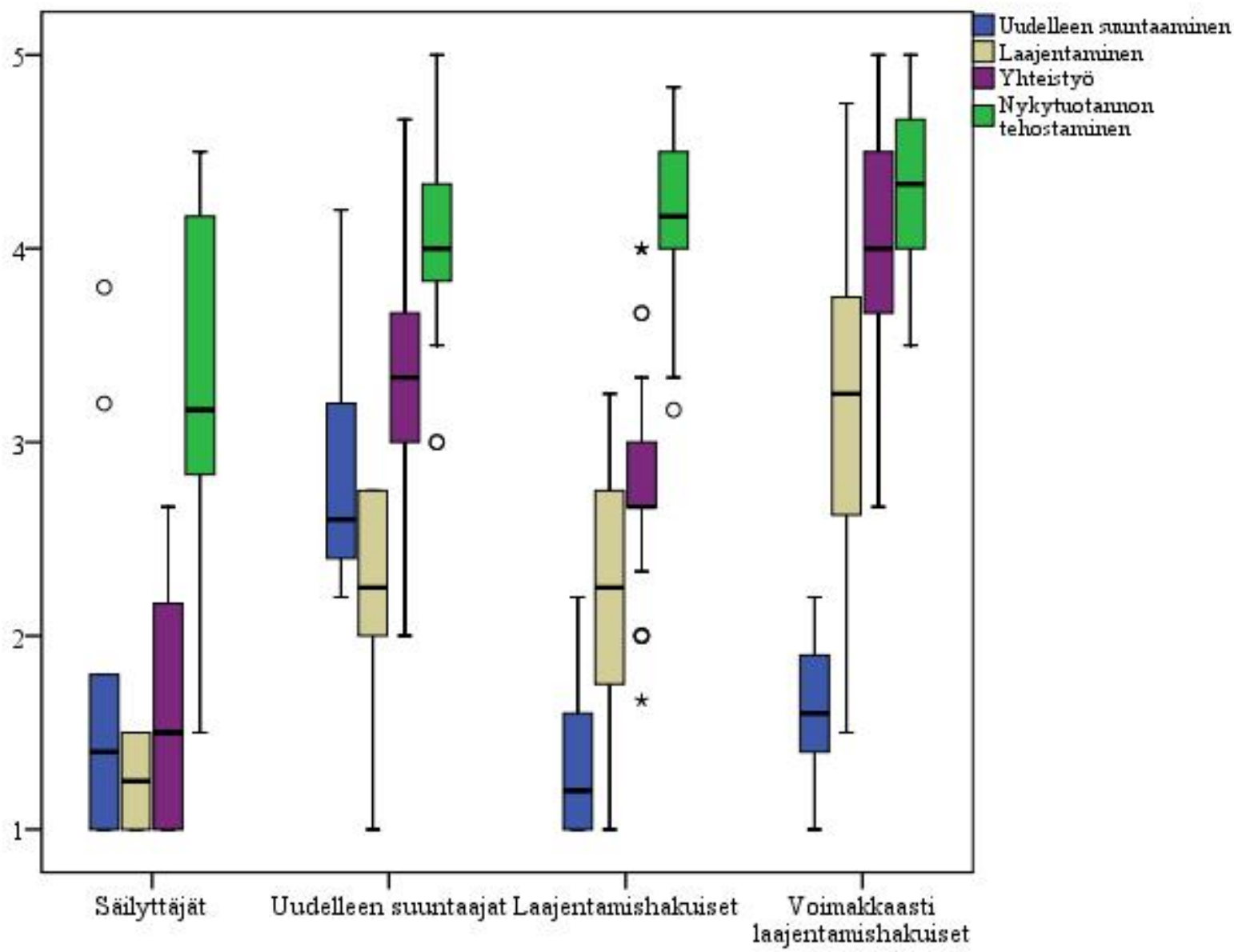

Suuntautumisryhmä

Kuvio 1. Maidontuottajien kehittämisaikomuksia kuvaavien summamuuttujien arvojen jakaumat kehittämisstrategioiden mukaisissa ryhmissä.

Erilaisten kehittämisstrategioiden mukaisiin ryhmiin kuuluvien maidontuottajien tilojen taloudellista tilannetta ja mennyttä kehitystä vuosina 2000 - 2007 arvioitiin tilinpäätöstietojen perusteella. Kokoa ja kasvua kuvaavina muuttujina analysoitiin liikevaihtoa, viljelyalaa ja työmäärää sekä niiden kehitystä em. vuosina. Taloudellista tulosta ja sen kehitystä arvioitiin vuoden 2007 yrittäjätulolla, kannattavuuskertoimen vuosien 2006 ja 2007 keskiarvolla, kannattavuuskertoimen vuosien 2000-2007 pitkän aikavälin keskiarvolla sekä kannattavuuskertoimen muutoksella vuosien 2000 ja 2001 keskiarvosta vuosien 2006 ja 2007 keskiarvoon. Pääomarakennetta ja sen kehitystä arvioitiin vuoden 2007 omavaraisuusasteella sekä omavaraisuusasteen muutoksella vuodesta 2000 vuoteen 2007. Taloudelliset tunnusluvut on esitetty tilaryhmittäin taulukoissa 2 - 4 . 
Taulukko 2. Tilojen kokoa kuvaavat tunnusluvut.

\begin{tabular}{|c|c|c|c|c|}
\hline Muuttuja & Tilaryhmä & $\mathbf{N}$ & Keskiarvo & Keskihajonta \\
\hline \multirow{5}{*}{$\begin{array}{l}\text { Liikevaihto } \\
2007, €\end{array}$} & Säilyttäjät & 11 & 109620 & 83461 \\
\hline & Uudelleen suuntaajat & 29 & 116801 & 45270 \\
\hline & Laajentamishakuiset & 28 & 200222 & 137098 \\
\hline & Voimakkaasti laajentamishakuiset & 42 & 243236 & 126530 \\
\hline & Kaikki tilat & 110 & 185592 & 122557 \\
\hline \multirow{5}{*}{$\begin{array}{l}\text { Työmäärä } \\
\text { 2007, h }\end{array}$} & Säilyttäjät & 11 & 3861 & 1116 \\
\hline & Uudelleen suuntaajat & 29 & 4194 & 1295 \\
\hline & Laajentamishakuiset & 28 & 4618 & 1702 \\
\hline & Voimakkaasti laajentamishakuiset & 42 & 4821 & 1797 \\
\hline & Kaikki tilat & 110 & 4508 & 1608 \\
\hline \multirow{5}{*}{$\begin{array}{l}\text { Taseen loppusumma } \\
2007, €\end{array}$} & Säilyttäjät & 11 & 284070 & 324626 \\
\hline & Uudelleen suuntaajat & 29 & 305919 & 138344 \\
\hline & Laajentamishakuiset & 28 & 638916 & 521922 \\
\hline & Voimakkaasti laajentamishakuiset & 42 & 767992 & 492813 \\
\hline & Kaikki tilat & 110 & 564925 & 465314 \\
\hline \multirow{5}{*}{$\begin{array}{l}\text { Viljelyala } \\
2007 \text {, ha }\end{array}$} & Säilyttäjät & 11 & 36,0 & 30,4 \\
\hline & Uudelleen suuntaajat & 29 & 44,9 & 21,1 \\
\hline & Laajentamishakuiset & 28 & 61,4 & 37,4 \\
\hline & Voimakkaasti laajentamishakuiset & 42 & 72,7 & 30,6 \\
\hline & Kaikki tilat & 110 & 58,8 & 32,8 \\
\hline
\end{tabular}

Yrityskoko vuonna 2007 niin liikevaihdolla, työtuntien määrällä, taseen loppusummalla kuin viljelyalallakin mitattuna oli suurin voimakkaasti laajentamishakuisilla ja pienin säilyttäjien ryhmään kuuluvilla maidontuottajilla. Yrityskoon kasvu noudatti lähes samaa säännönmukaisuutta: liikevaihto oli kasvanut vuodesta 2000 vuoteen 2007 niin absoluuttisesti kuin suhteellisestikin mitattuna eniten molemmissa laajentamishakuisten ryhmissä ja vähiten uudelleen suuntaajien ryhmässä. Viljelyalan kasvun osalta vastaavat erot eivät kuitenkaan olleet tilastollisesti merkitseviä. Keskimääräinen työtuntien määrä tarkasteluajanjakson aikana sen sijaan oli laskenut kaikissa tilaryhmissä, mutta erot ryhmien kesken eivät olleet tilastollisesti merkitseviä. Taseen loppusumman muutos vuodesta 2000 vuoteen 2007 oli suurin voimakkaasti laajentamishakuisten ryhmässä ja pienin uudelleen suuntaajien ryhmässä. Prosentuaalisesti mitaten taseen loppusumman kasvu oli kuitenkin voimakkainta laajentamishakuisten ryhmässä - keskimäärin lähes 100 prosenttia - ja vähäisintä säilyttäjien ryhmässä.

Taulukko 3. Tilojen kasvua kuvaavat tunnusluvut.

\begin{tabular}{|ll|r|r|r|}
\hline Muuttuja & Tilaryhmä & N & Keskiarvo & Keskihajonta \\
\hline Liikevaihdon muutos & Säilyttäjät & 6 & 41928 & 56252 \\
2000 & Uudelleen suuntaajat & 20 & 21419 & 21371 \\
-> 2007,€ & 21 & 49069 & 38626 \\
& Laajentamishakuiset & 23 & 101441 & 92862 \\
& Voimakkaasti laajentamishakuiset & 70 & 57765 & 67827 \\
\hline Kaikki tilat & 6 & 34,2 & 25,5 \\
\hline Liikevaihdon muutos & Säilyttäjät & & & \\
& & &
\end{tabular}

Maataloustieteen Päivät 2010. www.smts.fi. 


\begin{tabular}{|c|c|c|c|c|}
\hline \multirow{4}{*}{$\begin{array}{l}2000 \\
->2007, \%\end{array}$} & Uudelleen suuntaajat & 20 & 28,2 & 36,5 \\
\hline & Laajentamishakuiset & 21 & 36,6 & 29,9 \\
\hline & Voimakkaasti laajentamishakuiset & 23 & 67,1 & 41,6 \\
\hline & Kaikki tilat & 70 & 44,0 & 38,7 \\
\hline \multirow{5}{*}{$\begin{array}{l}\text { Työmäärän muutos } \\
2000 \\
->2007, \mathrm{~h}\end{array}$} & Säilyttäjät & 6 & & 1055 \\
\hline & Uudelleen suuntaajat & 20 & -1113 & 1559 \\
\hline & Laajentamishakuiset & 21 & -903 & 1758 \\
\hline & Voimakkaasti laajentamishakuiset & 23 & -840 & 966 \\
\hline & Kaikki tilat & 70 & -873 & 1419 \\
\hline \multirow{5}{*}{$\begin{array}{l}\text { Taseen loppusumman } \\
\text { muutos } \\
2000 \\
->2007, €\end{array}$} & Säilyttäjät & 6 & 110430 & 200965 \\
\hline & Uudelleen suuntaajat & 20 & 65618 & 107930 \\
\hline & Laajentamishakuiset & 21 & 310741 & 406225 \\
\hline & Voimakkaasti laajentamishakuiset & 23 & 368081 & 437112 \\
\hline & Kaikki tilat & 70 & 242377 & 363518 \\
\hline \multirow{5}{*}{$\begin{array}{l}\text { Taseen loppusumman } \\
\text { muutos } \\
2000->2007, \%\end{array}$} & Säilyttäjät & 6 & 24,3 & 26,7 \\
\hline & Uudelleen suuntaajat & 20 & 46,2 & 96,4 \\
\hline & Laajentamishakuiset & 21 & 95,0 & 124,4 \\
\hline & Voimakkaasti laajentamishakuiset & 23 & 87,5 & 77,7 \\
\hline & Kaikki tilat & 70 & 72,5 & 98,3 \\
\hline \multirow{5}{*}{$\begin{array}{l}\text { Viljelyalan muutos } \\
2000 \\
->2007 \text {, ha }\end{array}$} & Säilyttäjät & 6 & 5,5 & 6,6 \\
\hline & Uudelleen suuntaajat & 20 & 5,1 & 7,1 \\
\hline & Laajentamishakuiset & 21 & 12,2 & 16,2 \\
\hline & Voimakkaasti laajentamishakuiset & 23 & 10,9 & 19,2 \\
\hline & Kaikki tilat & 70 & 9,1 & 14,8 \\
\hline \multirow{5}{*}{$\begin{array}{l}\text { Viljelyalan muutos } \\
2000 \\
->2007, \%\end{array}$} & Säilyttäjät & 6 & 10,8 & 9,9 \\
\hline & Uudelleen suuntaajat & 20 & 19,5 & 42,7 \\
\hline & Laajentamishakuiset & 21 & 29,7 & 37,8 \\
\hline & Voimakkaasti laajentamishakuiset & 23 & 19,8 & 29,5 \\
\hline & Kaikki tilat & 70 & 21,9 & 35,1 \\
\hline
\end{tabular}

Kannattavuuskerroin vuosien 2006 ja 2007 keskiarvona sekä koko tarkasteluajanjakson keskiarvona oli korkein kasvuhakuisten yrittäjien ryhmässä ja alhaisin uudelleen suuntaajien ryhmässä. Tilaryhmien sisäinen vaihtelu oli kuitenkin huomattavaa, eivätkä erot ryhmien välillä siten olleet tilastollisesti merkitseviä. Kannattavuuskertoimen muutos ajanjakson aikana oli kaikissa tilaryhmissä negatiivinen (keskimäärin -0,24 yksikköä). Keskimäärin suurinta kannattavuuskertoimen lasku oli ollut voimakkaasti kasvuhakuisten ryhmässä, mutta tässäkään suhteessa ryhmien väliset erot eivät olleet tilastollisesti merkitseviä. Yrittäjätulo vuonna 2007 oli keskimäärin korkein laajentamishakuisten ja alhaisin säilyttäjien ryhmässä. Myös yrittäjätulon osalta ryhmien sisäinen vaihtelu oli hyvin huomattavaa, eivätkä erot siten olleet tilastollisesti merkitseviä.

Taulukko 4. Tilojen taloudellista tulosta kuvaavat tunnusluvut.

\begin{tabular}{|l|l|r|r|r|}
\hline Muuttuja & Tilaryhmä & N & Keskiarvo & Keskihajonta \\
\cline { 1 - 6 } Kannattavuuskerroin keskimäärin & \multirow{2}{*}{ Säilyttäjät } & 12 & 0,52 & 0,29 \\
\cline { 2 - 6 } & & &
\end{tabular}




\begin{tabular}{|c|c|c|c|c|}
\hline \multirow[t]{4}{*}{ 2006-2007 } & Uudelleen suuntaajat & 30 & 0,51 & 0,28 \\
\hline & Laajentamishakuiset & 29 & 0,66 & 0,37 \\
\hline & Voimakkaasti laajentamishakuiset & 44 & 0,58 & 0,58 \\
\hline & Kaikki tilat & 115 & 0,58 & 0,44 \\
\hline \multirow{5}{*}{$\begin{array}{l}\text { Kannattavuuskerroin keskimäärin } \\
\text { 2000-2007 }\end{array}$} & Säilyttäjät & 12 & 0,57 & 0,29 \\
\hline & Uudelleen suuntaajat & 30 & 0,54 & 0,21 \\
\hline & Laajentamishakuiset & 29 & 0,68 & 0,35 \\
\hline & Voimakkaasti laajentamishakuiset & 44 & 0,64 & 0,44 \\
\hline & Kaikki tilat & 115 & 0,62 & 0,35 \\
\hline \multirow{5}{*}{$\begin{array}{l}\text { Kannattavuuskertoimen muutos } \\
\text { 2000-2001 } \\
\text {-> 2006-2007, yks. }\end{array}$} & Säilyttäjät & 6 & $-0,22$ & 0,21 \\
\hline & Uudelleen suuntaajat & 20 & $-0,21$ & 0,29 \\
\hline & Laajentamishakuiset & 21 & $-0,24$ & 0,29 \\
\hline & Voimakkaasti laajentamishakuiset & 26 & $-0,27$ & 0,45 \\
\hline & Kaikki tilat & 73 & $-0,24$ & 0,34 \\
\hline \multirow{5}{*}{$\begin{array}{l}\text { Yrittäjätulo } \\
2007, €\end{array}$} & Säilyttäjät & 11 & 39610 & 31342 \\
\hline & Uudelleen suuntaajat & 29 & 39922 & 26647 \\
\hline & Laajentamishakuiset & 28 & 55764 & 43810 \\
\hline & Voimakkaasti laajentamishakuiset & 42 & 49911 & 53328 \\
\hline & Kaikki tilat & 110 & 47737 & 43115 \\
\hline \multirow{5}{*}{$\begin{array}{l}\text { Omavaraisuusaste } \\
\text { 2007, \% }\end{array}$} & Säilyttäjät & 11 & 89,3 & 11,4 \\
\hline & Uudelleen suuntaajat & 29 & 83,5 & 18,0 \\
\hline & Laajentamishakuiset & 28 & 80,4 & 20,5 \\
\hline & Voimakkaasti laajentamishakuiset & 42 & 70,3 & 25,9 \\
\hline & Kaikki tilat & 110 & 78,3 & 22,3 \\
\hline \multirow{5}{*}{$\begin{array}{l}\text { Omavaraisuusasteen muutos } \\
2000 \text {-> 2007, \% -yks. }\end{array}$} & Säilyttäjät & 6 & 3,8 & 5,0 \\
\hline & Uudelleen suuntaajat & 20 & 3,0 & 15,5 \\
\hline & Laajentamishakuiset & 21 & $-2,7$ & 24,0 \\
\hline & Voimakkaasti laajentamishakuiset & 23 & 3,6 & 18,6 \\
\hline & Kaikki tilat & 70 & 1,6 & 18,8 \\
\hline
\end{tabular}

Omavaraisuusaste vuonna 2007 oli aineistoon kuuluvilla tiloilla keskimäärin varsin korkea (78\%). Voimakkaasti kasvuhakuisten maidontuottajien tiloilla omavaraisuusaste oli kuitenkin tilastollisesti merkitsevästi alhaisempi kuin muissa ryhmissä. Kaikkein velkaisimmat maidontuottajat kuuluivatkin juuri voimakkaasti laajentamishakuisten ryhmään. Omavaraisuusaste oli tutkimusajanjakson aikana noussut kaikilla tiloilla keskimäärin vajaat kaksi porsenttiyksikköä, mutta laajentamishakuisten maidontuottajien ryhmässä muutos oli ollut keskimäärin vajaat kolme prosenttiyksikköä negatiivinen.

Maidontuottajan kehittämisstrategian ja tilan elinkaaren välistä yhteyttä tarkasteltiin ristiintaulukoinnin avulla niiden 111 tuottajan osalta, jotka olivat ao. kysymyksiin vastanneet. Analyysin keskeinen tulos oli, että kasvuhakuisten ryhmiin kuului odotettua enemmän niitä tuottajia, joilla kysymys sukupolvenvaihdoksesta oli ajankohtainen aikaisintaan $15 \mathrm{v}$ kuluttua ja vastaavasti uudelleen suuntaajissa oli odotettua enemmän tuottajia, joilla sukupolvenvaihdos oli juuri tehty tai joilla se oli ajankohtainen lähivuosina. Tiloista kymmenellä sukupolvenvaihdos oli tehty äskettäin. Näistä tuottajista neljä kuului uudelleen suuntaajien ryhmään ja viisi laajentamishakuisten ryhmiin. Kysymys sukupolvenvaihdoksesta oli ajankohtainen aikaisintaan 15 vuoden kuluttua 47 yrittäjälle, joista 36 kuului laajen- 
tamishakuisten ryhmiin ja kahdeksan uudelleen suuntaajien ryhmiin ja vain kolme säilyttäjiin. 44 yrittäjällä sukupolvenvaihdos oli ajankohtainen alle 15 vuoden kuluessa. Nämä jakautuivat suunnilleen tasan muihin kuin säilyttäjien ryhmiin. Tilanpidon mahdollisen jatkajan puuttuminen taas oli tyypillisintä säilyttäjien ryhmässä ja epätyypillisintä voimakkaasti laajentavien ryhmässä.

\section{Tulosten tarkastelu ja johtopäätökset}

Tässä tutkimuksessa tarkasteltiin 110:aa kannattavuuskirjanpitoon osallistuvaa maidontuottajaa ja heidän tilojaan. Aineiston pienuus sekä kirjanpitokyselyyn vastaamisen mahdollinen vääristynyt valikoituminen merkitsevät sitä, että tuloksista tehtäviin yleistyksiin on suhtauduttava tietyllä varovaisuudella.

Tutkimuksen tulosten perusteella näyttää kuitenkin siltä, että maidontuotannossa yrityskoon kasvu jatkuu. Kasvuhakuisuus on vahvinta tiloilla, joilla kasvu on ollut voimakasta jo viime vuosina. Voimakkaaseen kasvuhakuisuuteen liittyvä piirre on myös maidontuottajien voimakas tahto tiivistää yhteistyötä muiden yrittäjien sekä elintarvikeketjun muiden toimijoiden kanssa. Tämä on luonnollista, sillä yrityskoon kasvaessa omat resurssit eivät välttämättä riitä kaikkien tilan tuotantoon liittyvien työvaiheiden tekemiseen itse. Kasvuhakuiset maidontuottajat ovat muita valmiimpia lisäämään tilan velkataakkaa ja taloudellista riskiä. Tämä saattaa olla kasvun edellytys, mutta toisaalta se saattaa muodostua menestymiselle uhaksi, sillä kasvuhakuisten tuottajien tiloilla omavaraisuusaste on jo nyt keskimäärin alhaisempi kuin muilla tiloilla. Lisäksi kasvaneilla, edelleen voimakkaasti kasvuhakuisilla tuottajilla tilojen kannattavuus ei ole kehittynyt sen suotuisammin kuin muidenkaan maitotilojen, mikä edelleen lisää kasvuun liittyvää riskiä. Maataloudesta saatu yrittäjätulo on suurimmilla, kasvaneilla ja edelleen kasvuhakuisilla maidontuottajilla keskimäärin hieman korkeampi kuin muilla, mikä on tilan lyhyen aikavälin menestymisen kannalta kriittisen maksuvalmiuden säilyttämisen suhteen rohkaisevaa. Kasvuhakuisten maidontuottajien aiemmin toteutuneeseen tilakoon kasvuun liittyy luonnollisena osana maatalouteen sitoutuneen pääoman kasvu. Kun samaan aikaan on työmäärä tiloilla hieman vähentynyt, voidaan ilmiötä tulkita siten, että yhtenä kasvun edellytyksenä on ollut juuri työn korvaaminen pääomalla. Oman työn määrän vähentämisessä myös töiden ulkoistamisella on keskeinen merkitys (Karttunen ja Tuure 2008).

Tuotannon uudelleen suuntaaminen joko tuotteiden jatkojalostuksen, päätuotantosuunnan vaihtamisen tai sivuelinkeinon kehittämisen kautta on tyypillinen kehittämisstrategia pienimmillä, vähiten viime vuosina kasvaneilla tiloilla. Ilmiön taustalla vaikuttavia tekijöitä voivat olla maidontuottajien henkilökohtaisten mieltymysten lisäksi käytännön kasvun edellytysten puuttuminen kuten lisäpellon heikko saatavuus sekä halu välttää voimakkaan kasvun edellyttämää velkaisuuden kasvua. Maidontuotannosta luopuminen tai muiden tuotannonhaarojen tai sivuelinkeinojen kehittäminen näyttää olevan yhteydessä myös tilan sukupolvenvaihdoksen ajankohtaan. Perustavaa laatua oleville muutoksille tilan toiminnassa on luonteva ajankohta juuri tällöin. Myös mahdollisen tilanpidon jatkajan olemassaololla on merkitystä tuottajan kehittämisaikomuksille: jatkajan puuttuessa tyypillisiä kehittämisstrategioita ovat nykytuotannon säilyttäminen ja uudelleen suuntaaminen. Tilan kasvattamiseen liittyvät lisäpääoman ja sitoutumisen tarpeet eivät tällaisessa tilanteessa välttämättä tunnu houkuttelevilta.

Missä määrin maidontuottajien ilmaisemat kehittämisaikomukset voivat käytännössä toteutua, on paljolti riippuvainen kehittämisen edellytysten olemassaolosta. Niin lisäresurssien saatavuus kuin investoinneissa tarvittavan vieraan pääoman saatavuus ja hintakin ovat paikallisten olosuhteiden lisäksi riippuvaisia harjoitetusta rakennepolitiikasta, jolla voidaan edistää tuotannosta luopumista harkitsevien viljelijöiden resurssien siirtymistä kehittämishaluisille viljelijöille sekä turvata edullisen vieraan pääoman saatavuutta (vrt. Mäkinen ym. 1999, Latva-Kyyny 2009). Kuitenkin kriittisin tekijä kehittämisaikomusten toteutumisen kannalta on maidontuotannon yleinen kannattavuuskehitys. Jatkuvasti heikkenevä kannattavuus ei houkuttele tuottajia lisäämään yrittämiseen liittyvää riskiä ja sitoutumista maidontuotantoon. Osansa kannattavuuskehitykseen tuo myös harjoitettu tuotanto- ja tukipolitiikka sekä niiden kehittymiseen liittyvä epävarmuus. Tämän tutkimuksen luonnollinen jatko olisikin tarkastella muutaman vuoden kuluttua, miten viljelijöiden kehittämisstrategiat ovat käytännössä toteutuneet ja mitkä tekijät toteutumisasteeseen ovat keskeisimmin vaikuttaneet. 


\section{Kirjallisuus}

Karttunen, J. \& Tuure, V-M. 2008. Töiden organisointi perustuotanto- ja monialaisilla tiloilla. Julkaisussa: Maataloustieteen Päivät 2008 [verkkojulkaisu]. Suomen Maataloustieteellisen Seuran tiedotteita no 23. Toim. Anneli Hopponen. Viitattu [4.12.2009]. Julkaistu 9.1.2008. Saatavilla Internetissä: http://www.smts.fi. ISBN 978-951-9041-51-3.

Latva-Kyyny, M. 2009. Yrittäjyyden ja resurssien käytön muutos Etelä-Pohjanmaan maitotiloilla 2000-luvun alussa. Helsingin yliopisto, Taloustieteen laitos. Maatalousekonomian Pro Gradu -tutkielman käsikirjoitus.

Mäkinen, H., Ryhänen, M., Sipiläinen, T. \& Ylätalo, M. 1999. Tuotantoresurssien hankinta ja viljelijöiden tuotannon kehittämisaikomukset Vieremän kunnassa. Helsingin yliopisto, Taloustieteen laitoksen selvityksiä nro 7: 1-43.

Mäkinen Heikki \& Ylätalo Matti (2008). Strategic orientation Behind Success of Finnish Family Farms. Latvia University of Agriculture, Proceedings of the International Scientific conference "Economic Science for rural Development" nr 16: 91-99.

Hair, J., Black, W., Babin, B., Anderson, R. \& Tatham, R. 2005. Multivariate data analysis. 6. painos. Prentice Hall. 898 s. ISBN 0-13-032929-0 